DOI: https://doi.org/10.18524/2519-2523.2021.16.245736

УДК 94(477.74-21):061.2:63“"1869/1872”

\title{
PETRO SOKALSII'S PUBLICATIONS IN THE "NOTES OF THE IMPERIAL SOCIETY OF AGRICULTURE OF SOUTHERN RUSSIA” (1869-1872)
}

\section{Kseniia Sorokina}

Post-graduate student of the Department of History and Ethnography of Ukraine Odesa Polytechnic State University 1, T. Shevchenko Av., Odesa, 65044, Ukraine ORCID: https://orcid.org/00000002-4130-038X

E-mail: oksanawerty@gmail.com

Citation: Sorokina, K. (2021) Petro Sokalski's publications in the "Notes of the Imperial Society of Agriculture of Southern Russia" (1869-1872). Chornomors 'ka mynuvshyna, vol. 16, pp. $33-44$.

Submitted: 25.10 .2021

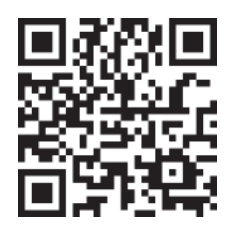

\section{Annotation}

The second essay in the cycle of the researches of the activities of the Ukrainian composer, publicist, active participant of the national movement of the second half of the XIX-th century Petro Sokalskyi (1832 - 1887) in the Imperial Society of Agriculture of Southern Russia focuses on the analysis of the authorial articles published in the volumes of «Notes of the Imperial Society of Agriculture of Southern Russia» during 1869-1872. Therefore, the classification of publications by thematic categories and their review in chronological order are the main tasks of the study. It was found out that Petro Sokalskyi not only held the positions of the secretary of the society and editor of "Notes" (from 1869 to 1871), but also actively wrote on agricultural topics. Author's articles of this period were the reviews of the problems of agriculture in the south of the empire in different years; the discussions of measures of encouraging the sheep farming and winemaking in the region; the descriptions of the results of the exhibition of viticulture and winemaking; and so on. The publicist also responded to questions that worried the farmers, winemakers and workers throughout the empire: economic and customs policy, the "wool issue", the labor issue and more.

In fact, on all the above issues, Sokalskyi expressed professional and deep thoughts, and also drew upon the

international and European experience, which underscored his general intelligence in different fields of knowledge. The characteristic of this part of the author's journalistic heritage allows not only to supplement the available biographical information, but also to draw the attention of researchers to individual members of the Imperial Society of Agriculture of Southern Russia. In addition, the authors' articles will be useful for agricultural researchers.

Key words: agriculture, Imperial Society of Agriculture of Southern Russia, "Notes of the Imperial Society of Agriculture of Southern Russia”, Petro Sokalskyi.

\section{ПУБЛПКЦӤ ПЕТРА СОКАЛЬСЫКОГО НА ШПАЛЬТАХ “ЗАПИСОК ИМПЕРАТОРСКОГО ОБЩЕСТВА СЕЛЬСКОГО ХОЗЯЙСТВА ЮЖНОЙ РОССИИ" (1869-1872 pp.)}

\section{Ксенія Сорокіна}

Аспірантка кафедри історії та етнографії України

Державний університет “Одеська політехніка"

Пр. Т. Шевченка,1, м. Одеса, 65044, Україна

ORCID: https://orcid.org/0000-00024130-038X

E-mail: oksanawerty@gmail.com

\section{Анотація}

У ичклі досліджень діяльності украӥнського композитора, публіциста, активного учасника наџіонального руху другої половини XIX cm. Петра Сокальського (1832-1887) в лавах Імператорського товариства сільського господарства Південної Росії ия публікація акиентує увагу на аналізі статей останнього, опублікованих в томах "Записок Імператорського товариства сільського господарства Південної Росії” 
Цитування: Сорокіна К. Публікації Петра Сокальського на шпальтах "Записок Императорского общества сельского хозяйства Южной России" (1869-1872 pp.).

Чорноморська минувшина: записки Відділу історії козацтва на півдні України: зб. наук. пр. / за. ред. В.А. Смолія. Одеса: ФОП Бондаренко М.О., 2021. Вип. 16. C. $33-44$.

Отримано: 25.10.2021 p. протягом 1869-1872 рр. Серед поставлених автором дослідження завдань: класифікаџія публікацій за тематичними категоріями та їх аналіз у хронологічному порядку. 3'ясовано, щчо обіймаючи одночасно посади секретаря товариства та редактора “Записок” (з 1869 р. по 1871 р.), Петро Сокальський також проявив себе як активний дописувач на сільськогосподарську тематику. Авторські статті даного періоду являли собою переважно огляди проблем сільського господарства на півдні імперії в різні роки; обговорення заходів щодо заохочення вівчарства та виноробства в регіоні; описи результатів виставки виноградарства та виноробства тощу. Також відгукувався публіцист і на питання, щзо тоді хвилювали господарів, виноробів та робітників усієї імперії: економічна та митна

політика, «вовняне питання», робоче питання тощо. Зазначено, щуо з усіх вищевказаних тем П. Сокальський висловлював професійні та глибокі думки, а також звертався до міжнародного та європейського досвіду, щзо підтверджує його загальну обізнаність у різних галузях знань. Загалом, характеристика даної частини публіцистичного доробку автора дозволяє не лише доповнити наявні біографічні відомості, але й привернути увагу дослідників до окремих постатей-діячів Імператорського товариства сільського господарства Південної Росії. Крім того, сільськогосподарські дослідження Петра Сокальського стануть у нагоді $i$ вченим-аграріям.

Ключові слова: сільське господарство, Імператорське товариство сільського господарства Південної Росії, "Записки Императорского общества сельского хазяйства Южной России”, Петро Сокальський.

В першій публікації [33] циклу досліджень діяльності українського композитора, публіциста, активного учасника національного руху другої половини XIX ст. Петра Сокальського (1832-1887) в лавах Імператорського товариства сільського господарства Південної Росії (далі - ІТСГ) протягом 1869-1871 pp., опублікованому на сторінках збірника “Чорноморська минувшина" (Випуск 15, 2020 р.) [33], ми вже звертали увагу на долю участі останнього в галузевих комісіях товариства. Крім того, нами була здійснена спроба бібліографування публіцистичної спадщини автора в “Записках Императорского общества сельского хазяйства Южной России” (далі - “Записки об-ва”). Складений перелік публікацій подавався як додаток до статті. Пропонована стаття у свою чергу являє собою логічне тематичне продовження означеної проблематики та створена з метою аналізу власне самих дописів Петра Сокальського в томах “Записок об-ва”. Серед поставлених завдань відповідно: розподіл публікацій за тематичними категоріями та їх характеристика у хронологічному порядку. Джерельною базою дослідження слугують томи “Записок общества” за 1869-1872 pp. Як матеріали довідкового характеру використано “Исторический обзор пятидесятилетия деятельности Императорского Общества сельского хозяйства южной России с 1828 по 1878 год” (1878 р.) [2] та “Систематический указатель статей, заметок, протоколов, отчетов и проч. помещенных в “Листках” и “Записках” Императорского Общества Сельского Хозяйства Южной России с 1830 по 1894” (1895 р.) [1].

Нагадаємо, що членство Петра Петровича в лавах ІТСГ розпочалося 21 листопада 1868 р. і тривало до 16 жовтня 1871 р.; 18 січня 1869 р. кандидатуру публіциста було одноголосно підтримано на виборах секретаря т-ва та редактора “Записок об-ва", що дозволило йому обійняти дві посади одночасно. Згідно з бібліографією публікацій, укладеної за виданням Боріневича А. С. [1], за окреслений час авторству Петра Сокальського належить 22 дописи (останній в томі “Записок об-ва" за 1872 р.), опубліковані, як від імені секретаря та редактора/редакції, так і за особистим підписом, в тому числі, з використанням скорочених 
форм (“П. Сок.”; “П. С.”). У жодній статті не вжито варіації псевдонімів Петра Сокальського, якими він повсюдно послуговувався як дописувач “Одесского вестника” (далі - “ОВ”). Імовірно, це можна пов'язати по-перше, зі статусом в ІТСГ, по-друге, зі спектром описуваних проблем (статистичні огляди, задачі сільського господарства на півдні, звіти роботи комісій тва, в той час, як в газеті псевдоніми використовувалися в основному для іронічної рубрики фейлетон).

Переходячи безпосередньо до розгляду даної частини публіцистичного доробку Петра Сокальського, вважаємо за необхідне розподілити її за низкою критеріїв:

1. Обсяг викладеного матеріалу - розлогі “Сельскохозяйственные обозрения” (18691871 рр.) та “Труды” галузевих комісій ІТСГ (1870 р). Сюди ж віднесемо “Беседы о виноделии во время выставки виноградарства и виноделия в Одессе, в октябре 1870 года” (1871 р.), “Беседы о виноделии во время выставки виноградарства и виноделия в Одессе, в октябре 1870 года (беседа вторая)" (1871р.) та масштабний “Отчет о выставке виноградарства и виноделия бывшей в г. Одессе при Императорском Обществе сельского хозяйства южной России с 8-го октября по 8-е ноября 1870 г." (1872р.). А також порівняно невеликі за обсягом звернення від редакції: "Взгляд на современные задачи сельского хозяйства Южной России (вместо предисловия от новой редакции Записок)” (1869р.); “От редакции” (1869р.) та тематичні дописи: "Переносные колодці” (1869 р.); “О хлебных червях и жучках” (1869 р.); “Наглядные признаки для определения погоды ближайших дней” (1869р.); “Исторический обзор. Влияние различных тарифов на шерстяное дело в Северо-Американском союзе” (1869р.); “О жатвенных машинах (По поводу испытания жатки Джонстона близ Одессы, 2 июля 1870 года" (1870 р.); "Несколько заключений по шерстяному вопросу” (1870р.); "Новейшие наблюдения в области рыбоводства” (1871 р.).

2. Проблематика огляду - повідомлення від редакції (що окреслювали коло обговорюваних на шпальтах “Записок о-ва” питань, плани ІТСГ тощо), виноробство та виноградарство краю, “вовняне питання”, інші теми (спостереження за кліматом та погодними умовами, робоче питання та ін.).

Далі здійснимо аналіз дописів Петра Петровича в залежності від тематичного наповнення та хронології їх виходу в світ.

Так, розглядаючи «повідомлення від редакції» зазначимо, що 22 лютим 1869 р. датовано першу авторську статтю “Взгляд на современные задачи сельского хозяйства Южной России. (Предисловие от новой Редакции Записок Общества)" за підписом "Редактор Записок Общ. С.Х. Юж. России П. П. Сокальский” [20]. Зауважимо, що 1871 р., успадкувавши від старшого брата Миколи Сокальського (відомий одеський публіцист, головний редактор “Одесского вестника" протягом 1857-1871рр.) редакцію провідного часопису Наддніпрянської України Петро Петрович також випускав авторські статті 3 позначенням “редактор-видавець П. П. Сокальський”, в той час, як Микола Петрович залишав на шпальтах лише скромні примітки «ред.». Проте з даних варіацій підпису стає зрозумілим, що і при ІТСГ, і в редакції “OB” Петро Сокальський поєднував одразу дві посади - секретаря товариства та редактора “Записок о-ва”, i, відповідно, головного редактора газети та ії видавця. Також викликає зацікавлення і сама форма статті - звернення від імені нової редакції, що є доволі нетиповим для Петра Петровича. По смерті брата та довготривалих бюрократичних процедурах 3 отримання дозволу на редагування “ОВ”, Сокальський не звертається до читачів 3 повідомлення про зміни в редакційному штаті. Лише, наприкінці 1871 р. на шпальтах газети 3'являється два невеликих оголошення “Об издании в 1872 году Одесского Вестника” [21-24] 3 курсом нової редакції на поліпшення та розширення тематичного наповнення часопису. Вірогідно, така поведінка публіциста 1871 р. пояснюється тяжкими переживаннями 3 приводу передчасної смерті брата та значним додатковим навантаженням від редакторської діяльності.

Повертаючись до допису 1869 р., коли Петро Петрович ще не був обтяжений родинними обставинами та зрештою отримав посаду, що дозволяла суміщати фах магістра хімії зі справою душі - публіцистикою - він “"позволил себе почесть нравственным долгом в этой первой книжке Записок, поделиться с читателями некоторыми мыслями как по хозяйству края, так и по участию в нем 
Общества”. В цілому, сучасне йому положення сільського господарства краю, Сокальський порівнював з “картиною - великої сім'ї, бідної та хворої, захопленої зненацька та стихіями та власною безтурботністю”, додаючи “куди не кинутися - всюди нестача; щойно одне поправили, інше руйнується; ледве зібрали грошей - дах підправити, як його вже рознесло бурею [...]”. Такі ідеї не були чимось новим для публіциста, так, ще 1860 р. він писав до “ОВ”: “Адже в нашому краї досить всякого добра: і сарана і падіж худоби і бруд - все це тяжкість на продуктивність краю. Від того, життя у нас дороге і позбавлене будь-якого комфорту, не дивлячись на значну частину цивілізації місцевого населення. [...] Сподіваємося, що знайдуться енергійні люди, які привели б до життя безтільні ідеї або, принаймні, будили б сплячих" [34].

В доповнення, у зверненні до читачів було актуалізовано увагу на основних проблемних моментах сільського господарства на півдні України, з-поміж яких:

Клімат (Сокальським надано опис кліматичних особливостей в історичній ретроспективі 3 акцентом на несприятливих погодних умовах, наріканням на відсутність систематичних спостережень над історією та атмосферними явищами і закликом на боротьбу зі стихіями. Ясно тому, що на Товаристві [...] лежить турбота про приведення “метеорологічного питання" [...] для інтересів нашого сільського господарства" - підсумовував публіцист.

- Землеробство (вміщено загальну думку щодо занепаду землеробства та запропоновано різноманітні засоби його порятунку, серед них - зменшення орних площ, глибока обробка землі, фермерський спосіб ведення господарства, правильне сільськогосподарське рахівництво, зручності з придбання капіталів та дешевої робочої сили тощо. "Сельскохозяйственное Общество старается служить многообразным интересам хозяйства, [...], ему предстоит принимать к своему сердцу все главные элементы сельскохозяйственной промышленности").

- Капітал (автор тішився отриманням дорогоцінної підтримки від Земського Банку Херсонської Губернії 1865 р., водночас, обурюючись відсутністю оборотного капіталу у господарств краю. У свою чергу, вихід із кризового стану на його думку, був би можливим за сприяння Одеського товариства взаємного кредиту).

Робоча сила (Сокальський наголошував на остаточному припиненні 1870 р. тимчасово обов'язкових відношень селян до власників. У зв'язку з чим, сільське господарство має бути готовим до кардинальних змін. "Обмежувати свободу пересування окремої особи - не сучасно, а щодо робітника - не розважливо” - додавав автор і щодо недосконалості паспортної системи).

- Сільськогосподарська техніка/ робоча худоба (запропоновано приділяти більшу кількість уваги покращенню якості робочої худоби. "Суспільство не може залишатися байдужим до всіх питань, пов'язаних з винокурінням та акцизною системою, на совісті якої лежить - частка провини у поступовому погіршенні нашої робочої та бійної худоби”).

- Вівчарство (зроблено ставку на забезпеченні внутрішніх ринків збуту, залишаючи закордонні за “стіною високого тарифу на іноземну вовну", що дозволило б подолати конкуренцію з боку австралійської вовняної сировини).

- Асоціації (зауважено на важкості прищеплення ідей асоціацій місцевому сільськогосподарському сектору. 3 числа вже наявних та дієвих асоціацій названо Земський Банк Херсонської Губернії, Одеське товариства взаємного кредиту та, безперечно, Імператорське товариство сільського господарства Південної Росії).

Особистість господаря "Його розумовий і моральний обрій - часто рішуче впливають на господарство” - записано Сокальським).

Як висновки до статті зазначено, що першість в “Записках о-ва” має належати вказівкам досвіду та практики саме місцевих господарів, за редактором же залишається посередництво в обміні знаннями, спостереженнями та корисними думками по господарству, однак, посередництво не байдуже, а самовіддане.

Останньою заміткою за 1869 р. аналогічно став підсумковий звіт “От редакции” [9], що аналізував результати роботи ІТСГ за рік та окреслював плани товариства на майбутнє. “Дай 
Бог нам виграти, а не програти 1870 року, але разом дай Бог, щоб наше господарство перестало бути азартною грою. На те є клуби",- звітував Сокальський [9, с. 794].

До звернень від імені редакції віднесемо також невелике вступне "Сельскохозяйственное обозрение" [14] за 1871 р., де Сокальський привітав читачів з новим роком; побажав вдалих врожаїв господарям; успіхів зусиллям земств у розповсюдженні освіти в народі; подякував “патріотам своєї землі” за любов до справи та допитливість, а також висловився на користь збільшення кількості сільськогосподарських виставок в регіоні.

Серед нарисів 3 проблематики «виноробства та виноградарства краю» викликають зацікавлення два тематичних дописи Сокальського “Беседы о виноделии во время выставки виноградарства и виноделия в Одессе, в октябре 1870 года" [28] та "Беседы о виноделии во время выставки виноградарства и виноделия в Одессе, в октябре 1870 года (беседа вторая)" за 1871 р. [29]. Перший повідомляв про провал з'їзду виноробів, оголошений на час проведення виставки виноградарства та виноробства в Одесі 1870 р. через недостатню явку учасників та його перетворення у тематичні бесіди за участю чотирьох виноробів з Криму та Херсонської губернії, ряду виноторговців, кавістів (фахівець 3 вин $-K . C$.), сільських господарів, професорів хімії (серед яких магістр хімії

Сокальський) та декількох осіб, зацікавлених в успіхах виноробства в краї - всього - 22 персони. “Бесіди ці - посилаюся на тих, що брали участь у них - залишили найприємніші спогади і наочно показали - скільки інтересу придбали б вони від присутності в них більш значної кількості представників 3 різних місцевостей виноробства південної Росії та Кавказу", - нарікав Петро Петрович [28, c. 357]. Далі додавався список обговорюваних питань (засоби розведення виноградної лози в певній місцевості; сорти лози, обробка плантацій, обрізка та підв'язування винограду, догляд за винами та ін.), де найбільшої популярності здобуло обговорення нагальних потреб виноробів. Зокрема, бессарабські (аккерманські) виноградарі намагалися домогтися дозволу гнати виноградний спирт на тих самих засадах, як це було дозволено кримським власникам садів (мова йде про певні акцизні пільги, що діяли з 1867 р. - К. С.). "Вважаю, що пільги, дані Криму могли б бути поширені і на окремі округи в Бессарабії [...]", - підсумовував першу частину бесід Петро Петрович [28, с. 378]. Друга частина бесід поклала в основу розгляду - нагрівання вина, як один із важливих засобів його покращення та збереження. Сокальським надавалися результати експертизи грітих та ненагрітих вин одних і тих саме сортів, проведених експертною

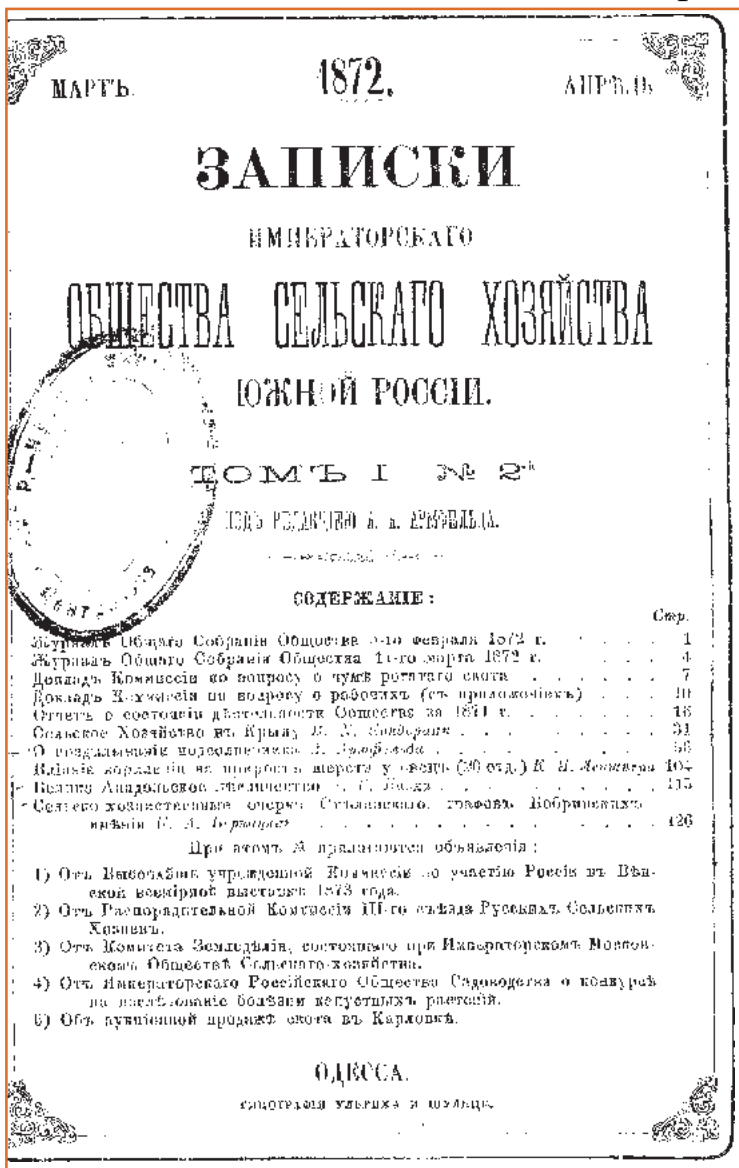

Обкладинка "Записок Императорского общества сельского хозяйства Южной России” за $1872 \mathrm{p}$. комісією на чолі із хіміком-виноробом. Участь в експерименті брав і безпосередньо Петро Петрович.

Органічним доповнення до попередніх бесід виявилася замітка Сокальського “Статистический и торговый очерк главнейших рынков для сбыта виноградного вина в Европе” [31] 1871 р. Нарис наголошував, що Московська 1864 р. та Одеська 1870 р. виставки вина пророкували блискавичне майбутнє імперським винам за умови усунення ускладнень переважно економічного характеру, надання кредитів виноробам та пошуку нових ринків збуту. Потому Петром Петровичем називалися головні ринки Європи для збуту виноградного вина (країни та міста), що мали особливе торговельне значення: Англія, Голландія, Швейцарія 
(з приміткою “можна помітити, що вона через низькі мита на вино і близькість кордону представляє дуже благодатне поле для виноробства сусідніх країн, але для російського ніякого" [31, с. 661]), Гамбург, Норвегія, Швеція, Стокгольм, Копенгаген, Данциг, Щетин, Кенігсберг, Константинополь, Трапезунд, Салоніки (збережено топоніміку XIX ст. $-K$. C.).

Вінцем публікацій з зазначеної теми, і принагідно, останньою публікацією Петра Сокальського в “Записках о-ва” став деталізований та масштабний “Отчет о выставке виноградарства и виноделия бывшей в г. Одессе при Императорском Обществе сельского хозяйства южной России с 8-го октября по 8-е ноября 1870 г." [30] за 1872 р., проаналізований нами в рамках фахової публікації “Петро Сокальський як діяч Імператорського Товариства Сільського Господарства Південної Росії (18691871)" [33]. Підкреслимо також, що за заслуги, виказані вітчизняному виноробству під час проведення означеної виставки 1871 р. Петро Сокальський отримав чин колезького асесора [2, с. 75 (додатки)].

"Исторический обзор влияний различных тарифов на шерстяное дело у СевероАмериканском Союзе" [3] 1869 р. перемістив вектор уваги Сокальського до галузі економіки, надто, до так званого “вовняного питання". Подібна зацікавленість легко пояснюється притаманним родині Сокальських інтересом до економічної науки в цілому, та інструментів торгової політики зокрема. До прикладу, згаданий вище, Микола Сокальський є автором низки тематичних статей до "ОВ" за 1860-ті рр. (наведені за посиланням) [25-27]. Крім того, в тематичному наповненні продовжував відчуватися вплив перебування Петра Петровича у США впродовж 1856-1858 pр. (детальніше у статті "Новий світ очима українця (за матеріалами публікацій П.П. Сокальського в “Одеському віснику” в 1859-1860рр.)” [32]). Власне, історичний огляд, описує кризу вовняної справи в Свропі, що склалася в 1860-х рр., через втрату американського ринку збуту (причинами тому - міжусобна війна у США та новий високий тариф). "Відтепер” - завершав виклад Сокальський - “європейській фабрикації вовняних виробів доводиться звернути свої погляди на відкриття нових ринків збуту - у південній Америці та Азії” [3, с. 578].

Далі в записках було викладено розлогий допис "Несколько заключений по шерстяному вопросу” 1870 р. [5] з розділу “Сельскохозяйственное обозрение”, який деталізував, вже відкритий Сокальським “шерстяной вопрос". Автор дописував, що не дійшовши консенсусу у розв'язанні низки питань (“як збільшити кількість вовни, при тих же витратах або поліпшити якість стада? Як здешевити перевезення вовни? Чи не можна розвинути кредит під вовну? У якій місцевості яка вівця вигідніша?”) і т. д. [5, с. 579]) члени ІТСГ звернулися до Московського Товариства Сільського Господарства 3 пропозицією розглянути на з’їзді з нагоди 50річного ювілею останнього, вплив ввізного до імперії закордонного прядива на хід та розвиток фабрик у Московській та суміжних губерніях, шкоду від введення охоронного мита на ввізну до імперії колоніальну вовну та вимоги вовняних фабрикантів. "Московское Общество, отнесясь с полным сочувствием и с радушной готовностью, заслуживающей искренней благодарности" [5, с. 581], зробило певні висновки, передані Петром Петровичем на майже двох десятках сторінок та доповнені власними роздумами 3 теми. Як висновок автор повідомляв про оголошення Московським Товариством Сільського Господарства регулярних з”їздів вівчарів, фабрикантів вовняних виробів та торговців вовною, які б дозволили “с глазу на глаз передавать друг другу обоюдные желания, и совершать сделки помимо лишних посредников”. В післямові до статті Сокальський також поділився передруком замітки 326 номера “Земледельческой газеты” за 1870 р., присвяченої питанням, поставленим на з'їзді вівчарів у рамках Харківської виставки мериносових овець [5, с. 605-610].

Друге за 1870 р. "Сельскохозяйственное обозрение" [12] стало тематичним продовженням попереднього допису та означило проблему виведення “вівці майбутнього” [12, c. 654] шляхом схрещення існуючих локальних видів 3 французькою породою рамбуйє або англійськими м'ясними породами овець. Особливо цікавили Петра Петровича зауваження 3 цього приводу, висловлені закордонними колегами, здебільшого, з Німеччини. Як і минулого разу, статтю доповнено тепер уже “Ответами харьковского съезда овцеводов на вопросы, бывшие на его обсужднии” [12, с. 662-664]. На завершення “Обозрения” було винесено зведення правил, існуючих в Одеському Комерційному Банку для виробництва позик під 
заставу товарів та продуктів. "Настільки невідкладна потреба в кредиті під сельс.хоз продукти тепер може задовольнятися цією новою установою”, - писав Сокальський [12, с. 674].

До публікацій з “вовняного питання” додамо і “Труды комиссии для обсуждения мер к поддержанию овцеводства в Новороссийском крае. Заседание 28-го ноября 1869 года”, “Труды комиссии для обсуждения мер к поддержанию овцеводства в Новороссийском крае. Заседание 1-го декабря 1869 года” та “Труды комиссии для обсуждения мер к поддержанию овцеводства в Новороссийском крае. Заседание 5-го декабря 1869 года” за 1870 р. [17-19].

Нижче охарактеризуємо нмзку нарисів віднесених нами до категорії “інші теми”. Зокрема, "Сельскохозяйственное обозрение" [11] 1869 р. розкрило читачам цілий спектр питань: австрійський рух на користь виробництва посівного насіння; німецькі каталоги насіння; розведення маку в Саксонії; практичні замітки відносно різноманітних кормових трав; злаки, що витримують посуху; люпин та кінський каштан у якості корму для худоби; кісткове борошно для корму; питання щодо зміни посівного насіння, вказівки Гельвінга; думки господарів; необхідність подальших спостережень. Зауважимо, що в даному дописі, як, втім, $\mathrm{i}$ в усіх інших, Петро Сокальський звернувся до місцевого та закордонного (європейського, американського) досвіду і виявив обізнаність в різних галузях знань.

Подібне "Сельскохозяйственное обозрение" [15], але вже за 1870 р., виявилося намаганням автора звернутися до робочого питання. В тому числі, виокремивши неповагу до власних зобов'язань, розпорошеність робочої сили на великому обширі півдня України, значну кількість прогульних днів та свят та недосконалі правила паспортної системи як чотирьох значних недоліків місцевої робочої праці, Петро Петрович спробував звернутися до практики окремих земств, зайнятих пошуками нових шляхів до вирішення проблеми. Висновки, до яких дійшов автор, надані ним у формі Pro et contra: так, гарне поводження з робітниками виступає проти незабезпеченості договорів; робочі книжки, як заміна паспортів - проти дистанцій місцевих землеробських територій; сприяння духівництва та за потреби, Синоду - проти розгулу та святкувань; полегшення пересування робітників - проти малонаселеності південних губерній [15, с. 764]. “Словом - питання величезного розміру, яке можуть подолати лише об'єднані зусилля уряду, - законод. та адміністрат. влади - суспільства у широкому сенсі, земства, духовенства, i - всемогутній час, не вбитий на пусті слова...” [15, с. 765] - довершив виклад Петро Петрович.

Ще одне “Сельскохозяйственное обозрение” [16] за 1870 р. в котре зачепило проблему сільськогосподарського кредитування. Останнє за Сокальським могло б принести лише малу частку користі господарям не зацікавленим в першу чергу у особистісних змінах, під якими автор розумів «возможность привести в ясность потери, или лучше сказать, богатства, которые сами даются в руки, и которых мы не умеем взять» (мова йде про недбале ставлення до посівних площ та посівного матеріалу, робочої худоби, зібраного збіжжя та ін. - $K$. C.). Вирішення проблеми, на думку Петра Петровича лежало в площині занять сільськогосподарською статистикою, через що, до статті докладалася "Програма хозяйственностатистических сведений” Департаменту Земельної та Сільської Промисловості з 20 таблиці та авторські примітки до неї. Зазначимо також, що згідно з текстом статті ця програма була розіслана товариством багатьом господарям, проте, не отримала жодної реакції. “Жодної серйозної справи не можна зробити ні з “любителями статистики", ні 3 любителями землеробства чи скотарства, - як не можна вести компанію 3 аматорами військового мистецтва. [...] Необхідна правильна, регулярна армія у будь-якій справі, і вона складається із фахівців, людей навчених своїй справі” [16, с. 841-842] - скаржився наостанок Сокальський.

Останнє за 1870 р. “Сельскохозяйственное обозрение” [13] сповістило читачів про отримання від Імператорського Російського Географічного товариства запрошення щодо сприяння дослідженням клімату імперії, через що, Рада ІТСГ доводила до відома господарів зразки бланків з прикладами оформлення. В бланку “Наблюдения за метеоритными осадками” пропонувалося вносити місце та автора спостережень, дату за старим та новим стилем, кількість, вид та тривалість опадів, а також, силу вітру. Бланки "Наблюдения над грозой" містили додаткові графи - напрямок та швидкість, сторона світу, а також, ушкодження, 
завдані стихією. Наприкінці “Обозрения” Сокальський також розмістив питання на сільськогосподарську тематику, надруковані в брошурі від Комітету землеробства при Московському Товаристві Сільського Господарства, обравши 3 них лише ті, що могли стосуватися системи господарювання в південних регіонах. Надамо окремі категорії розподілу питань: клімат, питання рільництва, зернові рослини, садівництво, робоча сила, кормові трави, збут та ін. У висновках Петро Петрович закликав господарів приділяти час для ознайомлення 3 актуальними проблемами сільського господарства та до відстеження погодних умов: “Саме, від небажання нашого вникнути у справу серйозно і дійти до подробиць і походить наша віра у легкість перемоги" [13, с. 924].

На останок розглянемо більш детально невеликі тематичні статті Сокальського за 1869 1871 pp. А саме, публікацію "Переносные колодці" [10] 1869 р., що довела до відома читачів передовий іноземний досвід використання так званих переносних трубчатих колодязів, налаштованих на видобуток води в усіх місцевостях, де $\epsilon$ імовірність її залягання на певній глибині. Авторство винаходу згідно з Сокальським належало США доби міжусобної війни, самі ж колодязі зазнали активного вжитку англійськими військовими під час Абіссинської експедиції. "Нічого й казати, що переносним колодязям пророкують найрізноманітніші застосування в промисловості, сільському господарстві, садівництві, городництві, тютюнництві, луківництві, скотарстві, у госпіталях, у постачанні водою міст і сіл, парових машин і локомотивів залізниць, а також при гасінні пожеж”, - підкреслював Петро Петрович $[10$, с. 78$]$. Значна вартість колодязя та необхідність замовлення іноземного устаткування для його експлуатації, а також, посушливі кліматичні умови, значно ускладнювали можливість використання останнього у степових регіонах, все ж, Сокальський повідомляв і про місцевого господаря, що погодився випробувати винахід.

Черговий допис “О хлебных жучках и червях" [8] 1869 р. сповістив господарів відносно шкідника (укр. “борошняний хробак” (личинка хрущака борошняного) - K. C.), що завдавав значної шкоди хлібним посівам, перебуваючи, як на стадії личинки, так й імаго. Як метод боротьби - Сокальським було запропоновано своєчасне винищення комах, до збору яких пропонувалося залучати в тому числі дітей. У додатку до статті було вміщено звернення голови Одеської повітової земської управи щодо появи в регіоні гусені, здатної до знищення значних посівних площ, приналежність даного виду до борошняного хробака піддавалася сумніву Петром Петровичем, однак, все ж вимагала реакції від місцевих господарств.

Замітка "Наглядные признаки для определения погоды ближайших дней” [4], вміщена 1869 р. до розділу «Смесь», тематично продовжила висновки Сокальського про роль погодних умов у розвитку сільського господарства, викладені в “Предисловии от новой Редакции Записок Общества" [20]. За автором, у кожного господаря в арсеналі перебувала низка прикмет, виокремлених ним із довготривалої практики задля контролю погодних змін. Господарям пропонувалося ділитися власними спостереженнями на сторінках “Записок о-ва”, самим же Петром Петровичем, як зачинателя теми, було виділено низку природних факторів, що допомагали відслідковувати примхи погоди. До них автор відніс: стан неба, звичайні та дощові хмари; вітри; тумани; росу; грім та блискавку; вплив місяця; зірки; веселку та води.

Стаття “О жатвенных машинах. (По поводу испытания жатки Джонстона близ Одессы, 2 июля 1870 года)" [7] 1870 р. підкреслила зацікавленість місцевих господарів жниварками, факт їх придбання та, в той самий час, відсутність практичного досвіду використання, на противагу широкому застосуванню такого роду сільськогосподарської техніки в Європі та США. У свою чергу, випробування нового типу жниварки від Джонстона успішно відбулося на учбовій фермі Новоросійського університету, а серед iї переваг Сокальський виділив порівняно легку вагу, рівну викладку зрізаного хліба та можливість жати лежалі посіви. "Чем ближе хозяйство подходит к фермерскому, тем более задатков для выгодной затраты денег на эту машину” [7, с. 536] - наголошував автор.

В останній короткій замітці “Новейшие наблюдения в области рыбоводства” 1871 р. [6], Сокальський означив фактори впливу на смертність риб (зараження стічної води нечистотами, 
сильні зливи, електричний стан повітря (удари блискавки), атмосферна теплота) та запропонував як шлях вирішення проблеми - ії штучне вирощування.

Отже, розглянуті вище публікації дозволяють віднести Петра Сокальського не тільки до когорти діяльних членів одеських товариств, в нашому випадку, Імператорського товариства сільського господарства Південної Росії, але й до числа найбільш активних дописувачів на сільськогосподарську тематику на шпальтах “Записок общества” впродовж 1869-1872 рр. Як секретаря та одночасно редактора друкованого органу ІТСГ Петра Петровича не залишали байдужими економічні та сільськогосподарські проблеми півдня України. Це обумовило найрізноманітнішу тематику зазначених публікацій - від спостережень за кліматом до боротьби зі шкідниками тощо. Також відгукувався Сокальський і на питання, що тоді хвилювали господарів, виноробів та робітників усієї імперії: економічна та митна політика, «вовняне питання», робоче питання, проблеми виноробства та виноградарства краю. Фактично, з усіх перелічених проблем, Петро Петрович висловлював фахові та грунтовні думки, а також звертався до передового загальносвітового досвіду, що підкреслювало його загальну обізнаність з різних галузей знань. Загалом, дослідження публікацій Сокальського на шпальтах «Записок о-ва» дозволяє не лише доповнити наявні біографічні відомості, але й привернути увагу вчених до окремих постатей-членів Імператорського товариства сільського господарства Південної Росії. Крім того, авторський публіцистичний доробок стане у нагоді і дослідникам-аграріям.

\section{Джерела та література:}

1. Бориневич А. С. Систематический указатель статей, заметок, протоколов, отчетов и проч. помещенных в “Листках" и “Записках" Императорского Общества Сельского Хозяйства Южной России с 1830 по 1894. Одесса : “Славянская” тип. Н. Христогелос, 1895. 130 с.

2. Исторический обзор пятидесятилетия деятельности Императорского Общества сельского хозяйства южной России с 1828 по 1878 год / сост. секретарем О-ва М.П. Боровским. Одесса : Тип. П. Францова, 1878.278 с.

3. [П.С.] Исторический обзор. Влияние различных тарифов на шерстяное дело в СевероАмериканском союзе. Записки Императорского Общества сельского хозяйства Южной России (далі-ЗИОСХЮР). 1869. С. 573-578.

4. [П.С.] Наглядные признаки для определения погоды ближайших дней. ЗИОСХЮР. 1869. C. 237-243.

5. [П.С.] Несколько заключений по шерстяному вопросу. ЗИОСХЮР. 1870. С. 577-610.

6. [П.С.] Новейшие наблюдения в области рыбоводства. ЗИОСХЮР. 1871. С. 142-152.

7. [П.С.] О жатвенных машинах (По поводу испытания жатки Джонстона близ Одессы, 2 июля 1870 года). ЗИОСХЮР. 1870. С. 523-536.

8. [П.С.] О хлебных червях и жучках. ЗИОСХЮР. 1869. С. 215-221.

9. [П.С.] От редакции. ЗИОСХЮР. 1869. С. 790-794.

10.[П.С.] Переносные колодцы. ЗИОСХЮР. 1869. С. 76-81.

11.[П.С.] Сельскохозяйственное обозрение. ЗИОСХЮР. 1869. С. 774-783.

12.[П.С.] Сельскохозяйственное обозрение. ЗИОСХЮР. 1870. С. 654-680.

13.[П.С.] Сельскохозяйственное обозрение. ЗИОСХЮР. 1870. С. 906-924.

14.[П.С.] Сельскохозяйственное обозрение. ЗИОСХЮР. 1871. С. 76-88.

15.[П. Сок.] Сельскохозяйственное обозрение. ЗИОСХЮР. 1870. С. 744-765.

16.[П. Сок.] Сельскохозяйственное обозрение. ЗИОСХЮР. 1870. С. 823-842.

17.[П. Сок.] Труды комиссии для обсуждения мер к поддержанию овцеводства в Новороссийском крае. Заседание 28-го ноября 1869 года. ЗИОСХЮР. 1870. С. 179-185.

18.[П. Сок.] Труды комиссии для обсуждения мер к поддержанию овцеводства в Новороссийском крае. Заседание 1-го декабря 1869 года. ЗИОСХЮР. 1870. С. 186-193.

19.[П. Сок.] Труды комиссии для обсуждения мер к поддержанию овцеводства в Новороссийском крае. Заседание 5-го декабря 1869 года. ЗИОСХЮР. 1870. С. 194-213. 
20. Редактор Записок Императорского Общества сельского хозяйства Южной России Петр Петрович Сокальский Взгляд на современные задачи сельского хозяйства Южной России (вместо предисловия от новой редакции Записок). ЗИОСХЮР. 1869. С. 15-29.

21.Редактор - издатель П. П. Сокальский Объявление об издании Одесского Вестника в 1872 году. Одесский вестник (далі - ОВ). 1871. 4 нояб.

22.Редактор - издатель П. П. Сокальский Об издании Одесского Вестника в 1872 году Одесского Вестника. ОВ. 1871. 10 нояб.

23. Редактор - издатель П. П. Сокальский Об издании в 1872 году Одесского Вестника. ОВ. 1871.14 нояб.

24. Редактор - издатель П. П. Сокальский Об издании в 1872 году Одесского Вестника. OB. 1871.5 дек.

25.Сокальский Н. Исторический очерк торговли Новороссийского края за последнее время. Ст. 1 : 1856-1857 г. ОВ. 1859. № 1 / Содержание Одесского Вестника за 1859-й г. OB. 1860.

26.Сокальский Н. Исторический очерк торговли Новороссийского края за последнее время. Ст. 2 : Торговый кризис. ОВ. 1859. № 2 / Содержание Одесского Вестника за 1859-й г. ОВ. 1860.

27.Сокальский Н. Исторический очерк торговли Новороссийского края за последнее время. Ст. 3 : 1858 г. OB. 1859. № 3 / Содержание Одесского Вестника за 1859-й г. OВ. 1860.

28.Сокальский П. Беседы о виноделии во время выставки виноградарства и виноделия в Одессе, в октябре 1870 года. ЗИОСХЮР. 1871. С. 355-378.

29.Сокальский П. Беседы о виноделии во время выставки виноградарства и виноделия в Одессе, в октябре 1870 года (беседа вторая). ЗИОСХЮР. 1871. С. 561-570.

30.Сокальский П. П. Отчет о выставке виноградарства и виноделия бывшей в г. Одессе при Императорском Обществе сельского хозяйства южной России с 8-го октября по 8-е ноября 1870 г. ЗИОСХЮР. 1872. Т. 1, № 3. С. 29-115.

31.Сокальский П. Сельскохозяйственное обозрение. Статистический и торговый очерк главнейших рынков для сбыта виноградного вина в Европе. ЗИОСХЮР. 1871. С. 637-669.

32.Сорокіна К.І. Новий світ очима українця (за матеріалами публікацій П. П. Сокальського в “Одеському віснику” в 1859-1860 рр.). Українське порто-франко: наук. студент. пр. 3 вітчизн. історії. Одеса, 2015. Вип. 2. С. 76-85.

33.Сорокіна К. І. Петро Сокальський як діяч Імператорського товариства сільського господарства Південної Росії (1869-1871). Чорноморська Минувиина : зап. Від. історії козацтва на півдні України : зб. наук. пр. 2020. Вип. 15. С. 39-46.

34.Фагот Фельетон. Одесский листок. $O B .1860 .1$ дек.

\section{References:}

1. Borinevich, A. S. (1895) Sistematicheskiy ukazatel statey, zametok, protokolov, otchetov i proch. pomeshchennykh v "Listkakh" $i$ "Zapiskakh" Imperatorskogo Obshchestva Selskogo Khozyaystva Yuzhnoy Rossii s 1830 po 1894. Odessa: "Slavyanskaya" tip. N. Khristogelos. [in Russian].

2. Borovskim M. P., comp. (1878) Istoricheskiy obzor pyatidesyatiletiya deyatelnosti Imperatorskogo Obshchestva selskogo khozyaystva yuzhnoy Rossii s 1828 po 1878 god. Odessa: Tip. P. Frantsova. [in Russian].

3. [P.S.] (1869) Istoricheskiy obzor. Vliyaniye razlichnykh tarifov na sherstyanoye delo v SeveroAmerikanskom soyuze. Zapiski Imperatorskogo obshchestva selskogo khozyaystva Yuzhnoy Rossii, pp. 573-578. [in Russian].

4. [P.S.] (1869) Naglyadnyye priznaki dlya opredeleniya pogody blizhayshikh dney. Zapiski Imperatorskogo obshchestva selskogo khozyaystva Yuzhnoy Rossii, pp. 237-243. [in Russian].

5. [P.S.] (1870) Neskolko zaklyucheniy po sherstyanomu voprosu. Zapiski Imperatorskogo obshchestva selskogo khozyaystva Yuzhnoy Rossii, pp. 577-610. [in Russian].

6. [P.S.] (1871) Noveyshiye nablyudeniya v oblasti rybovodstva. Zapiski Imperatorskogo obshchestva selskogo khozyaystva Yuzhnoy Rossii, pp.142-152. [in Russian]. 
7. [P.S.] (1870) O zhatvennykh mashinakh (Po povodu ispytaniya zhatki Dzhonstona bliz Odessy. 2 iyulya 1870 goda). Zapiski Imperatorskogo obshchestva selskogo khozyaystva Yuzhnoy Rossii. pp. 523-536. [in Russian].

8. [P.S.] (1869) O khlebnykh chervyakh i zhuchkakh. Zapiski Imperatorskogo obshchestva selskogo khozyaystva Yuzhnoy Rossii, pp. 215-221. [in Russian].

9. [P.S.] (1869) Ot redaktsii. Zapiski Imperatorskogo obshchestva selskogo khozyaystva Yuzhnoy Rossii, pp. 790-794. [in Russian].

10. [P.S.] (1869) Perenosnyye kolodtsy. Zapiski Imperatorskogo obshchestva selskogo khozyaystva Yuzhnoy Rossii, pp. 76-81. [in Russian].

11. [P.S.] (1869) Selskokhozyaystvennoye obozreniye. Zapiski Imperatorskogo obshchestva selskogo khozyaystva Yuzhnoy Rossii, pp. 774-783. [in Russian].

12. [P.S.] (1870) Selskokhozyaystvennoye obozreniye. Zapiski Imperatorskogo obshchestva selskogo khozyaystva Yuzhnoy Rossii, pp. 654-680. [in Russian].

13. [P.S.] (1870) Selskokhozyaystvennoye obozreniye. Zapiski Imperatorskogo obshchestva selskogo khozyaystva Yuzhnoy Rossii, pp. 906-924. [in Russian].

14. [P.S.] (1871) Selskokhozyaystvennoye obozreniye. Zapiski Imperatorskogo obshchestva selskogo khozyaystva Yuzhnoy Rossii, pp. 76-88. [in Russian].

15. [P. Sok.] (1870) Selskokhozyaystvennoye obozreniye. Zapiski Imperatorskogo obshchestva selskogo khozyaystva Yuzhnoy Rossii, pp. 744-765. [in Russian].

16. [P. Sok.] (1870) Selskokhozyaystvennoye obozreniye. Zapiski Imperatorskogo obshchestva selskogo khozyaystva Yuzhnoy Rossii, pp. 823-842. [in Russian].

17. [P. Sok.] (1870) Trudy komissii dlya obsuzhdeniya mer k podderzhaniyu ovtsevodstva v Novorossiyskom kraye. Zasedaniye 28-go noyabrya 1869 goda. Zapiski Imperatorskogo obshchestva selskogo khozyaystva Yuzhnoy Rossii, pp. 179-185. [in Russian].

18. [P. Sok.] (1870) Trudy komissii dlya obsuzhdeniya mer k podderzhaniyu ovtsevodstva v Novorossiyskom kraye. Zasedaniye 1-go dekabrya 1869 goda. Zapiski Imperatorskogo obshchestva selskogo khozyaystva Yuzhnoy Rossii, pp. 186-193. [in Russian].

19. [P. Sok.] (1870) Trudy komissii dlya obsuzhdeniya mer k podderzhaniyu ovtsevodstva v Novorossiyskom kraye. Zasedaniye 5-go dekabrya 1869 goda. Zapiski Imperatorskogo obshchestva selskogo khozyaystva Yuzhnoy Rossii, pp. 194-213. [in Russian].

20. Redaktor Zapisok Imperatorskogo Obshchestva selskogo khozyaystva Yuzhnoy Rossii Petr Petrovich Sokalskiy (1869) Vzglyad na sovremennyye zadachi selskogo khozyaystva Yuzhnoy Rossii (vmesto predisloviya ot novoy redaktsii Zapisok). Zapiski Imperatorskogo Obshchestva selskogo khozyaystva Yuzhnoy Rossii, pp. 15-29. [in Russian].

21. Redaktor-izdatel P.P.Sokalskii (1871) Obyavleniye ob izdanii Odesskogo Vestnika v 1872 godu. Odesskiy vestnik, 4 Nov. [in Russian].

22. Redaktor-izdatel P.P.Sokalskii (1871) Ob izdanii Odesskogo Vestnika v 1872 godu Odesskogo Vestnika. Odesskiy vestnik, 10 Nov. [in Russian].

23. Redaktor-izdatel P.P.Sokalskii (1871) Ob izdanii v 1872 godu Odesskogo Vestnika. Odesskiy vestnik, 14 Nov. [in Russian].

24. Redaktor-izdatel P.P.Sokalskii (1871) Ob izdanii v 1872 godu Odesskogo Vestnika. Odesskiy vestnik, 5 Dec. [in Russian].

25. Sokalskii N. (1859) Istoricheskii ocherk torgovli Novorossiyskogo kraya za posledneye vremya: St. 1: 1856-1857 g. / Soderzhaniye Odesskogo Vestnika za 1859-y g. Odesskiy vestnik, 1860. [in Russian].

26. Sokalskiy N. (1859) Istoricheskiy ocherk torgovli Novorossiyskogo kraya za posledneye vremya. St. 2: Torgovyy krizis / Soderzhaniye Odesskogo Vestnika za 1859-y g. Odesskiy vestnik, 1860. [in Russian].

27. Sokalskiy N. (1859) Istoricheskiy ocherk torgovli Novorossiyskogo kraya za posledneye vremya. St. 3: 1858 g. / Soderzhaniye Odesskogo Vestnika za 1859-y g. Odesskiy vestnik, 1860. [in Russian].

28. Sokalskiy P. (1871) Besedy o vinodelii vo vremya vystavki vinogradarstva i vinodeliya v Odesse. v oktyabre 1870 goda. Zapiski Imperatorskogo obshchestva selskogo khozyaystva Yuzhnoy Rossii, pp. 355378. [in Russian]. 
29. Sokalskiy P. (1871) Besedy o vinodelii vo vremya vystavki vinogradarstva i vinodeliya v Odesse. v oktyabre 1870 goda (beseda vtoraya). Zapiski Imperatorskogo obshchestva selskogo khozyaystva Yuzhnoy Rossii, pp. 561-570. [in Russian].

30. Sokalskiy P. P. (1872) Otchet o vystavke vinogradarstva i vinodeliya byvshey v g. Odesse pri Imperatorskom Obshchestve selskogo khozyaystva yuzhnoy Rossii s 8-go oktyabrya po 8-e noyabrya $1870 \mathrm{~g}$. Zapiski Imperatorskogo obshchestva selskogo khozyaystva Yuzhnoy Rossii, vol. 1, no. 3, pp. 29-115. [in Russian].

31. Sokalskiy P. (1871) Selskokhozyaystvennoye obozreniye. Statisticheskiy i torgovyy ocherk glavneyshikh rynkov dlya sbyta vinogradnogo vina v Evrope. Zapiski Imperatorskogo obshchestva selskogo khozyaystva Yuzhnoy Rossii, pp. 637-669. [in Russian].

32. Sorokina K.I. (2015) Novyi svit ochyma ukraintsia (za materialamy publikatsii P.P. Sokalskoho v «Odeskomu visnyku» v 1859-1860 rr.). Ukrainske porto-franko: naukovi studentski pratsi z vitchyznianoi istorii. Odesa: Bukaiev Vadym Viktorovych, vol. 2, pp. 76-85. [in Ukrainian].

33. Sorokina K.I. (2020) Petro Sokalskyi yak diiach Imperatorskoho tovarystva silskoho hospodarstva Pivdennoï Rosiï (1869-1871). Chornomorska Mynuvshyna, vol. 15, pp. 39-46. [in Ukrainian].

34. Fagot (1860) Felyeton.Odesskiy listok. Odesskiy vestnik, 1 Dec. [in Russian]. 